\title{
Pengaruh musim terhadap kelimpahan kumbang moncong (Coleoptera: Curculionidae) pada tipe penggunaan lahan berbeda di lanskap Hutan Harapan dan Taman Nasional Bukit Duabelas, Jambi
}

\author{
Seasonal abundance of weevils (Coleoptera: Curculionidae) in \\ different land-use types in Hutan Harapan and Bukit Duabelas \\ National Park Landscapes, Jambi \\ Fatimah Siddikah $^{1}{ }^{*}$, Rizky Nazarreta $^{1}$, Damayanti Buchori $^{1,2}$ \\ ${ }^{1}$ Departemen Proteksi Tanaman, Fakultas Pertanian, Institut Pertanian Bogor \\ Jalan Kamper, Kampus IPB Dramaga, Bogor 16680 \\ ${ }^{2}$ Center for Transdisciplinary and Sustainability Science (CTSS), IPB University \\ Jalan Raya Pajajaran No. 27, Bogor 16128
}

(diterima Agustus 2019, disetujui Juni 2020)

\begin{abstract}
ABSTRAK
Perubahan fungsi tipe penggunaan lahan dari hutan menjadi perkebunan dapat menyebabkan hilangnya berbagai jenis keanekaragaman serangga, salah satunya adalah kelompok kumbang. Kumbang Curculionidae atau kumbang moncong merupakan salah satu famili terbesar dalam Ordo Coleoptera karena kemampuannya yang mampu beradaptasi di hampir semua habitat di alam. Penelitian ini bertujuan untuk mempelajari pengaruh musim terhadap kekayaan spesies dan kelimpahan individu kumbang moncong pada tipe penggunaan lahan perkebunan kelapa sawit dan karet di area lanskap Hutan Harapan dan Taman Nasional Bukit Duabelas, Jambi. Pengambilan sampel dilakukan pada musim kemarau dan musim hujan 2013-2014 dengan metode pengasapan menggunakan pestisida berbahan aktif piretroid. Pada setiap tipe penggunaan lahan (perkebunan kelapa sawit dan karet) ditentukan 4 plot pengamatan, dan masing-masing plot pengamatan ditentukan 3 titik sebagai subplot sehingga total keseluruhan terdapat 16 plot atau 48 subplot. Hasil penelitian menunjukkan bahwa ditemukan sebanyak 1.761 individu kumbang moncong yang terdiri atas 9 subfamili dan 45 morfospesies. Berdasarkan hasil analisis, perbedaan musim tidak memengaruhi kekayaan spesies dan kelimpahan individu, sedangkan perbedaan tipe penggunaan lahan hanya memengaruhi kelimpahan individu kumbang moncong. Berdasarkan hasil analisis kemiripan spesies Bray-Curtis menunjukkan sebesar $4 \%$ terjadi kemiripan spesies antar tipe penggunaan lahan, dan $46 \%$ kemiripan spesies antar musim. Hasil analisis indeks keanekaragaman pada tipe penggunaan lahan kelapa sawit lebih rendah dibandingkan dengan tipe penggunaan lahan karet. Salah satu spesies dominan yang ditemukan pada kedua tipe penggunaan lahan adalah Elaeidobius kamerunicus Faust., juga ditemukan spesies spesifik yang hanya menempati tipe penggunaan lahan tertentu, seperti Rhynchophorus sp.01 hanya ditemukan pada tipe penggunaan lahan perkebunan kelapa sawit, dan Curculio sp.04 hanya ditemukan pada tipe penggunaan lahan karet.
\end{abstract}

Kata kunci: Elaeidobius kamerunicus, kanopi, karet, keanekaragaman, kelapa sawit

\begin{abstract}
Land-use change from forest to plantation can cause the loss of various types of insect diversity group, one of which is the beetle group. Curculionids or weevils is one of the largest families in the Order Coleoptera due to its adaptability in almost all habitats in nature. This research is aimed

*Penulis korespondensi: Fatimah Siddikah. Departemen Proteksi Tanaman, Fakultas Pertanian, Institut Pertanian Bogor

Jalan Kamper, Kampus IPB Dramaga, Bogor 16680, Tel: 0251-8629364, Faks: 0251-8629363, Email: fatimah.siddikah@yahoo.com
\end{abstract}


to study the effect of seasonality on species richness and the abundance of weevils in oil palm and rubber plantation in Hutan Harapan and Bukit Duabelas National Park, Jambi. Sample was collected in the dry season and rainy season 2013-2014 by fogging method using pyrethroid knockdown insecticides. In each land-use, 4 observation plots were erected with selected 3 points as a subplots, so there are 16 plots or 48 subplots in total. The results showed that 1.761 individuals of weevils from 9 subfamilies and 45 morphospecies. Based on analysis, seasonal difference did not affect species richness and abundance of weevils, while land-use types affect abundance of weevils. Analysis of similarity using Bray-Curtis Index showed $4 \%$ of similarity in two land-use types, and $46 \%$ of similarity between two seasons. The diversity index in oil palm plantation were lower than rubber plantation. The most dominant species that can be found in both land-use types is Elaeidobius kamerunicus Faust., while Rhynchophorus sp.01 is only found in oil palm plantation, and Curculio sp.04 is only found in rubber plantation.

Key words: abundance, canopy, Elaeidobius kamerunicus, oil palm, rubber

\section{PENDAHULUAN}

Provinsi Jambi merupakan salah satu provinsi di Indonesia yang memiliki areal perkebunan yang cukup luas dan mengalami peningkatan setiap tahunnya (Ditjenbun 2019a; Ditjenbun 2019b). Perkebunan kelapa sawit di Jambi mengalami peningkatan sekitar 25 ribu ha dari tahun 2018 menjadi 931.790 ha pada tahun 2019 (Ditjenbun 2019a). Begitupula pada perkebunan karet yang juga mengalami peningkatan 766 ha dari tahun 2018 ke tahun 2019 menjadi 379.461 ha (Ditjenbun 2019b). Meningkatnya luasan areal perkebunan yang berarti meningkatkan intensifikasi penggunaan lahan menjadi monokultur. Hal tersebut dilaporkan dapat memberikan dampak negatif terhadap keanekaragaman dan kepadatan invertebrata (Mumme et al. 2015).

Perubahan penggunaan lahan dari hutan ke penggunaan lahan intensif, seperti perkebunan karet dan perkebunan kelapa sawit menurunkan kekayaan spesies secara signifikan, terutama pada kelompok makro-invertebrata yang berperan sebagai predator, seperti kumbang predator (Mumme et al. 2015). Beberapa penelitian juga menunjukkan terjadi penurunan yang signifikan terhadap kekayaan spesies pada beberapa famili dari kumbang Coleoptera akibat adanya perubahan penggunaan lahan, seperti pada Famili Curculionidae (Najmi et al. 2018), Famili Elateridae (Kasmiatun et al. 2020a), Famili Staphylinidae (Hiola 2019), serta Famili Chrysomelidae (Amrulloh 2020).

Kumbang merupakan jenis serangga dari Ordo Coleoptera yang memiliki keanekaragaman dan kelimpahan tertinggi dari kelompok serangga, yaitu sebanyak $40 \%$ dari total populasi serangga di alam (Lawrence \& Britton 1991), hal ini karena kemampuannya yang dapat beradaptasi di hampir semua jenis habitat (Arnett \& Thomas 2001). Kumbang Curculionidae atau kumbang moncong adalah famili dari Ordo Coleoptera yang memiliki keanekaragaman tertinggi. Lebih dari 4.600 genus dan 51.000 spesies yang sudah berhasil diidentifikasi (Oberprieler et al. 2007; Hangay \& Zborowski 2010). Kumbang moncong tersebar hampir di seluruh dunia, lebih dari 2.600 spesiesnya terdapat di Amerika Utara, dan sebanyak 6.000 spesiesnya berasal dari Australia (Lawrence \& Britton 1991; Borror et al. 1996).

Kumbang moncong merupakan salah satu famili yang memiliki peranan penting di ekosistem, sebagian besar berperan sebagai hama-hama yang serius pada tanaman pertanian, tanaman hias, perkebunan, bahkan di penyimpanan (Anderson 2002), seperti Rhynchophorus ferrugineus (Olivier) yang merupakan hama pada tanaman palem-paleman dan dapat menyebabkan kerusakan parah dan kematian pada tanaman (Anderson 2002; Faleiro et al. 2002). Selain itu, adapula yang memiliki peranan penting, yaitu Elaeidobius kamerunicus Faust. yang berperan sebagai penyerbuk utama tanaman kelapa sawit (O’Brien \& Woodruff 1986; Syed 1979).

Penelitian mengenai kumbang moncong yang pernah dilakukan sebelumnya oleh Najmi et al. (2018) terbatas pada kekayaan spesies dan kelimpahan individu kumbang moncong di empat tipe penggunaan lahan berbeda di Hutan Harapan, Jambi, sedangkan pada penelitian ini selain membahas kekayaan spesies dan kelimpahan individu di penggunaan lahan kelapa sawit dan 
karet, juga akan membahas pengaruh musim terhadap keanekaragaman kumbang moncong. Oleh karena itu, tujuan dari penelitian ini untuk memelajari kekayaan, kelimpahan individu serta komposisi spesies kumbang moncong di perkebunan kelapa sawit dan karet pada musim yang berbeda di lanskap Hutan Harapan dan Taman Nasional Bukit Duabelas, dan diharapkan dapat memberikan data dasar terkait keanekaragaman spesies dan kelimpahan individu kumbang moncong di perkebunan kelapa sawit dan karet di Jambi.

\section{BAHAN DAN METODE}

\section{Lokasi penelitian}

Pengambilan sampel dilakukan pada musim kemarau (Mei sampai Oktober 2013) dan musim hujan (November 2013 sampai Maret 2014) di lanskap Hutan Harapan dan Taman Nasional Bukit Duabelas, Jambi (Gambar 1). Lokasi pengambilan sampel dipetakan dengan menggunakan global positioning system (GPS). Rancangan yang digunakan adalah rancangan acak lengkap (RAL). Pada setiap lanskap ditentukan dua tipe penggunaan lahan, yaitu perkebunan kelapa sawit dan karet sehingga terdapat 4 tipe penggunaan lahan. Masing-masing tipe penggunaan lahan ditentukan 4 plot pengamatan yang berukuran 50 $\mathrm{m} \times 50 \mathrm{~m}$, dari masing-masing plot dipilih 3 titik sebagai subplot, kemudian diulang pada musim yang berbeda dengan plot pengamatan yang sama sehingga total keseluruhan terdapat 16 plot atau 48 subplot.

\section{Pengambilan sampel}

Metode pengambilan sampel pada penelitian ini mengacu pada Drescher et al. (2016). Pengambilan sampel dilakukan dengan teknik pengasapan (fogging) di pagi hari pukul 06.00 WIB dengan menggunakan pestisida berbahan aktif piretroid pada setiap subplot yang sudah ditentukan. Sebanyak 16 wadah berukuran $1 \mathrm{~m} \mathrm{x}$ $1 \mathrm{~m}$ berbentuk limas terbalik di pasang di bawah kanopi pohon yang terpilih, yang di bawahnya telah diberi botol plastik berisi alkohol $96 \%$ dengan label di masing-masing botol berdasarkan kode tempat pengambilan sampel (mengacu pada Kasmiatun et al. 2020b, Gambar 2). Pengasapan dilakukan selama 20 menit secara vertikal kearah kanopi pohon. Setelah pengasapan, kemudian ditunggu selama 2 jam hingga serangga jatuh pada perangkap dan dikumpulkan pada botol plastik untuk setiap subplot. Selanjutnya botol plastik berisi koleksi serangga yang telah dikumpulkan dibawa ke laboratorium untuk proses identifikasi.

\section{Identifikasi kumbang moncong}

Sampel yang telah dikumpulkan diidentifikasi di laboratorium dengan menggunakan mikroskop stereo. Proses identifikasi diawali dengan

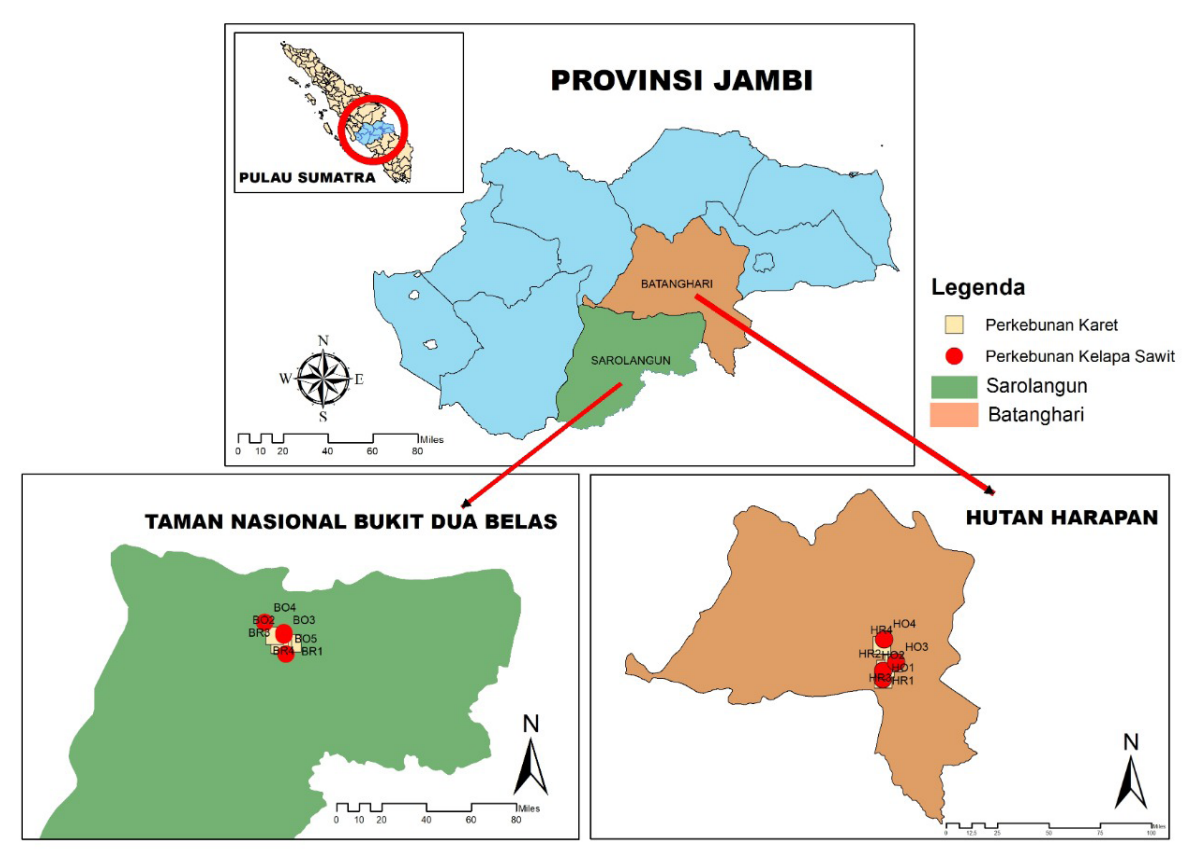

Gambar 1. Peta lokasi penelitian di Jambi. 
memisahkan spesimen berdasarkan tingkat ordo, kemudian untuk Ordo Coleoptera disortir kembali hingga tingkat famili, dan untuk Famili Curculionidae diambil untuk diidentifikasi hingga tingkat morfospesies. Buku kunci identifikasi yang digunakan adalah American Beetles, Volume II (Arnett et al. 2002), Family Curculionidae (Kippenberg 1981).

\section{Analisis data}

Data hasil identifikasi kumbang moncong ditabulasikan ke dalam pivot table dengan menggunakan perangkat lunak Microsoft Excel. Pengaruh perbedaan musim dan tipe penggunaan lahan terhadap kelimpahan dan kekayaan spesies kumbang moncong dianalisis ragam (one way ANOVA). Indeks keanekaragaman ShannonWienner $(\mathrm{H})$, kemerataan Evennes (E), keanekaragaman spesies Simpson (D) digunakan untuk melihat keanekaragaman kumbang moncong di perkebunan kelapa sawit dan karet (Ludwig \& Reynolds 1988), sedangkan untuk mengetahui pengaruh perbedaan tipe penggunaan lahan dan musim terhadap struktur komposisi kumbang moncong dianalisis menggunakan analysis of similarity (ANOSIM) dan grafik non-metric multidimensional scalling (NMDS) untuk memberikan visualisasi perbedaan struktur komposisi spesies kumbang moncong. Data diolah dengan menggunakan perangkat lunak RStudio.

\section{HASIL}

\section{Keanekaragaman morfospesies kumbang moncong di kedua lanskap}

Jumlah keseluruhan kumbang moncong yang ditemukan di lanskap Hutan Harapan dan Taman Nasional Bukit Duabelas sebanyak 1.761 individu yang terdiri atas 9 subfamili dan 45 morfospesies. Jumlah morfospesies kumbang moncong yang ditemukan di lanskap Taman Nasional Bukit Duabelas lebih tinggi (879 individu, 8 subfamili, 31 morfospesies) dibandingkan dengan lanskap Hutan Harapan (882 individu, 7 subfamili, 26 morfospesies). Sebanyak 12 morfospesies kumbang moncong dapat dijumpai pada kedua lanskap, seperti E. kamerunicus, Anthonomus sp.06, Orchestes sp.01, Platypus sp.01, dan Hypothenemus sp.01 (Tabel 1, Gambar 2).
Selain itu terdapat 14 morfospesies kumbang moncong yang hanya ditemukan di lanskap Hutan Harapan, seperti Brimoides sp.02, Platypus sp.03, Ambrosiodmus sp.01, dan Hypothenemus sp.04 (Tabel 1, Gambar 3). Sebanyak 19 morfospesies kumbang moncong hanya ditemukan di lanskap Taman Nasional Bukit Duabelas, seperti Baris sp.02, Curculio sp.04, Treptoplatypus sp.01, dan Alniphagus sp.01 (Tabel 1, Gambar 4).

\section{Kekayaan kumbang moncong di perkebunan karet dan kelapa sawit berdasarkan pengaruh lanskap dan musim}

Secara keseluruhan, kekayaan kumbang moncong yang ditemukan di perkebunan karet (30 morfospesies) tidak jauh berbeda dengan perkebunan kelapa sawit (29 morfospesies), namun berpengaruh nyata terhadap kelimpahan individu $\left(\mathrm{F}_{3,12}=5,75 ; \mathrm{P}=0,011 ; \mathrm{N}=16\right)$. Berdasarkan diagram boxplot (Gambar 5), tampak bahwa jumlah individu pada perkebunan kelapa sawit lebih banyak dibandingkan dengan perkebunan karet, sedangkan jumlah spesies di kedua tipe penggunaan lahan tidak jauh berbeda. Terdapat 16 morfospesies kumbang moncong hanya ditemukan pada perkebunan karet, seperti Curculio sp.04 dan Brimoides sp.02 (Tabel 1, Gambar 6) dan terdapat 15 morfospesies kumbang moncong yang hanya ditemukan di perkebunan kelapa sawit, seperti Rhynchophorus sp.01 dan Baris sp.02 (Tabel 1, Gambar 7).

Begitu juga dengan perbedaan musim yang tidak memberikan pengaruh terhadap kelimpahan individu $\left(\mathrm{F}_{1,30}=3,322 ; \mathrm{P}=0,078 ; \mathrm{N}=32\right)$ dan kekayaan spesies $\left(\mathrm{F}_{1,30}=0,008 ; \mathrm{P}=0,927 ; \mathrm{N}=\right.$ 32). Morfospesies kumbang moncong yang hanya ditemukan pada musim kemarau di antaranya adalah Baris sp.02, Platypus sp.03, Treptoplatypus sp.01, Hypotenemus sp.03, dan Hypotenemus sp.04, sedangkan morfospesies kumbang moncong yang hanya ditemukan pada musim hujan di antaranya adalah Brimoides sp.02, Cossonus sp.02, Curculio sp.04, dan Scolytogenes sp.01. Selain itu terdapat morfospesies kumbang moncong yang ditemukan mendominasi di kedua musim, yaitu E. kamerunicus, Hypothenemus sp.01, Cossoninae sp.02, dan Platypus sp.01.

Berdasarkan hasil analisis kemiripan komposisi spesies dengan menggunakan indeks Bray-Curtis, perbedaan musim dan lanskap 
Tabel 1. Daftar morfospesies kumbang moncong yang ditemukan di perkebunan kelapa sawit dan karet di kedua lanskap dan musim

\begin{tabular}{|c|c|c|c|c|c|c|}
\hline \multirow{2}{*}{$\begin{array}{l}\text { Subfamili } \\
\text { Morfospesies }\end{array}$} & \multicolumn{2}{|c|}{ Hutan Harapan } & \multicolumn{2}{|c|}{$\begin{array}{c}\text { Taman Nasional Bukit } \\
\text { Duabelas }\end{array}$} & \multicolumn{2}{|c|}{ Musim } \\
\hline & Kelapa sawit & Karet & Kelapa sawit & Karet & Kemarau & Hujan \\
\hline \multicolumn{7}{|l|}{ Baridinae } \\
\hline Baris sp.02 & 0 & 0 & 1 & 0 & 1 & 0 \\
\hline \multicolumn{7}{|l|}{ Conoderinae } \\
\hline Brimoides sp.02 & 0 & 1 & 0 & 0 & 0 & 1 \\
\hline Conoderinae sp. 12 & 0 & 1 & 0 & 0 & 1 & 0 \\
\hline Conoderinae sp.14 & 1 & 0 & 0 & 0 & 1 & 0 \\
\hline \multicolumn{7}{|l|}{ Cossoninae } \\
\hline Cossoninae sp.01 & 9 & 0 & 0 & 0 & 0 & 9 \\
\hline Cossoninae sp.02 & 12 & 3 & 8 & 0 & 10 & 13 \\
\hline Cossonus sp.01 & 1 & 5 & 1 & 0 & 5 & 2 \\
\hline Cossonus sp.02 & 0 & 1 & 0 & 0 & 0 & 1 \\
\hline \multicolumn{7}{|l|}{ Cryptorhynchinae } \\
\hline Cryptorhynchinae sp.01 & 0 & 1 & 0 & 0 & 0 & 1 \\
\hline Cryptorhynchinae sp.02 & 0 & 0 & 0 & 4 & 0 & 4 \\
\hline Cryptorhynchinae sp.04 & 0 & 1 & 0 & 0 & 1 & 0 \\
\hline Cryptorhynchinae sp.07 & 1 & 0 & 0 & 0 & 0 & 1 \\
\hline Cryptorhynchinae sp.19 & 0 & 0 & 1 & 0 & 1 & 0 \\
\hline Cryptorhynchinae sp.21 & 0 & 0 & 0 & 1 & 1 & 0 \\
\hline Cryptorhynchinae sp.27 & 0 & 2 & 0 & 0 & 2 & 0 \\
\hline Cryptorhynchinae sp. 33 & 0 & 0 & 1 & 0 & 0 & 1 \\
\hline Cryptorhynchinae sp.43 & 0 & 0 & 0 & 1 & 1 & 0 \\
\hline Cryptorhynchinae sp.49 & 0 & 3 & 1 & 1 & 3 & 2 \\
\hline \multicolumn{7}{|l|}{ Curculioninae } \\
\hline Anthonomus sp.06 & 1 & 3 & 1 & 0 & 3 & 2 \\
\hline Curculio sp.04 & 0 & 0 & 0 & 1 & 0 & 1 \\
\hline Curculioninae sp.01 & 0 & 0 & 5 & 2 & 2 & 5 \\
\hline Curculioninae sp.04 & 0 & 0 & 1 & 0 & 1 & 0 \\
\hline Curculioninae sp.18 & 0 & 1 & 2 & 0 & 3 & 0 \\
\hline Elaeidobius kamerunicus & 793 & 2 & 810 & 2 & 376 & 1231 \\
\hline Notolomus sp.01 & 2 & 0 & 2 & 1 & 4 & 1 \\
\hline Orchestes sp.01 & 0 & 1 & 1 & 1 & 2 & 1 \\
\hline \multicolumn{7}{|l|}{ Dryophthorinae } \\
\hline Rhynchophorus sp.01 & 3 & 0 & 2 & 0 & 3 & 2 \\
\hline \multicolumn{7}{|l|}{ Molytinae } \\
\hline Molytinae sp.12 & 0 & 0 & 0 & 1 & & 1 \\
\hline \multicolumn{7}{|l|}{ Platypodinae } \\
\hline Platypodinae sp.05 & 0 & 0 & 1 & 0 & 1 & \\
\hline Platypus sp.01 & 5 & 0 & 6 & 4 & 6 & 9 \\
\hline Platypus sp.02 & 5 & 0 & 0 & 0 & 0 & 5 \\
\hline Platypus sp.03 & 1 & 0 & 0 & 0 & 1 & 0 \\
\hline Treptoplatypus sp.01 & 0 & 0 & 1 & 0 & 1 & 0 \\
\hline
\end{tabular}


Tabel 1. (Lanjutan.)

\begin{tabular}{|c|c|c|c|c|c|c|}
\hline \multirow{2}{*}{$\begin{array}{l}\text { Subfamili } \\
\text { Morfospesies }\end{array}$} & \multicolumn{2}{|c|}{ Hutan Harapan } & \multicolumn{2}{|c|}{$\begin{array}{c}\text { Taman Nasional Bukit } \\
\text { Duabelas }\end{array}$} & \multicolumn{2}{|c|}{ Musim } \\
\hline & Kelapa sawit & Karet & Kelapa sawit & Karet & Kemarau & Hujan \\
\hline \multicolumn{7}{|l|}{ Scolytinae } \\
\hline Alniphagus sp.01 & 0 & 0 & 0 & 1 & 1 & 0 \\
\hline Ambrosiodmus sp.01 & 0 & 1 & 0 & 0 & 1 & 0 \\
\hline Hypothenemus sp.01 & 13 & 4 & 1 & 3 & 1 & 20 \\
\hline Hypothenemus sp.03 & 0 & 0 & 1 & 0 & 1 & 0 \\
\hline Hypothenemus sp.04 & 0 & 1 & 0 & 0 & 1 & 0 \\
\hline Phloeotribus sp.01 & 0 & 0 & 1 & 1 & 0 & 2 \\
\hline Scolytinae sp.01 & 0 & 0 & 1 & 1 & 2 & 0 \\
\hline Scolytinae sp.03 & 0 & 0 & 1 & 0 & 1 & 0 \\
\hline Scolytinae sp.06 & 0 & 1 & 0 & 0 & 0 & 1 \\
\hline Scolytinae sp.07 & 2 & 1 & 0 & 2 & 3 & 2 \\
\hline Scolytinae sp.08 & 0 & 0 & 0 & 1 & 1 & 0 \\
\hline Scolytogenes sp.01 & 0 & 0 & 1 & 0 & 0 & 1 \\
\hline Total & 849 & 33 & 851 & 28 & 442 & 1319 \\
\hline
\end{tabular}
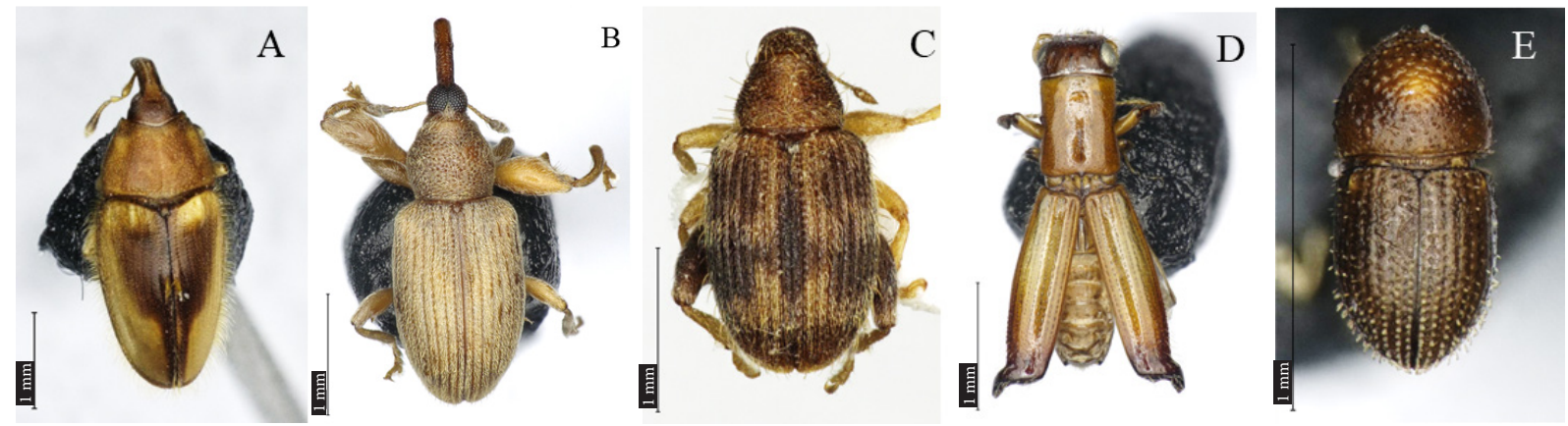

Gambar 2. Kumbang moncong yang ditemukan di kedua tipe penggunaan lahan. A: Elaeidobius kamerunicus; B: Anthonomus sp.06; C: Orchestes sp.01; D: Platypus sp.01; dan E: Hypothenemus sp.01.
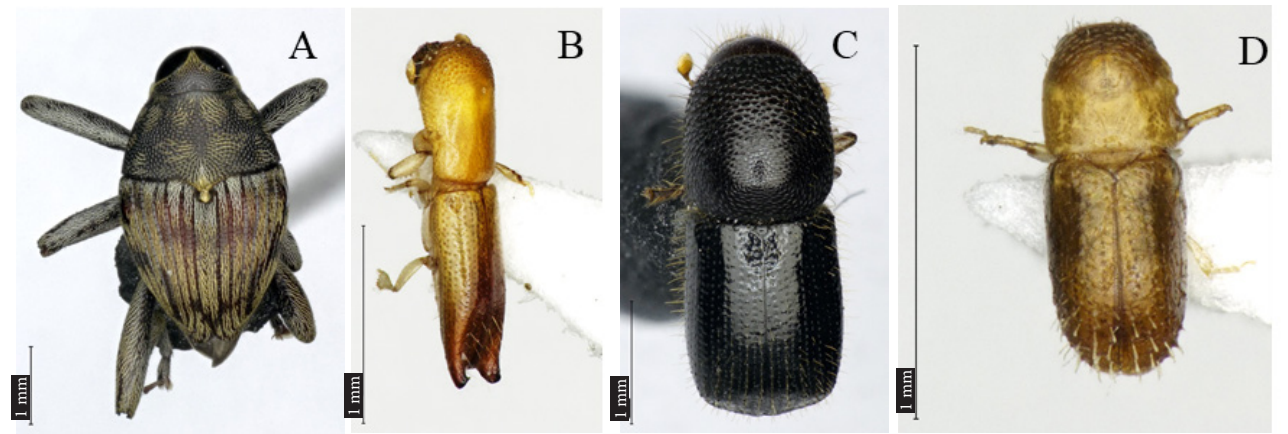

Gambar 3. Kumbang moncong yang hanya ditemukan di Hutan Harapan. A: Brimoides sp.02, B: Platypus sp.03, C: Ambrosiodmus sp.01; dan D: Hypothenemus sp.04. 

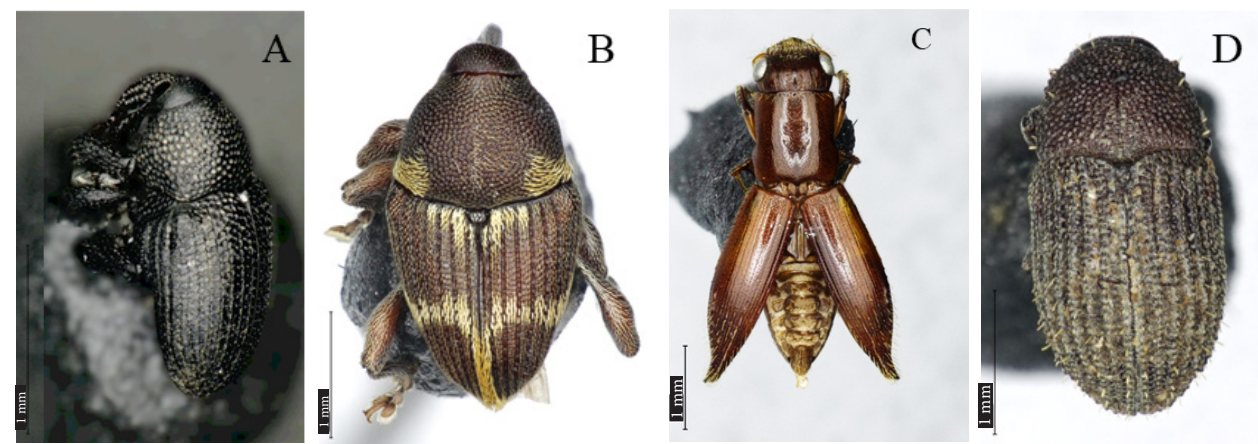

Gambar 4. Kumbang moncong yang hanya ditemukan di Taman Nasional Bukit Duabelas. A: Baris sp.02; B: Curculio sp.04; C: Treptoplatypus sp.01; D: Alniphagus sp.01.

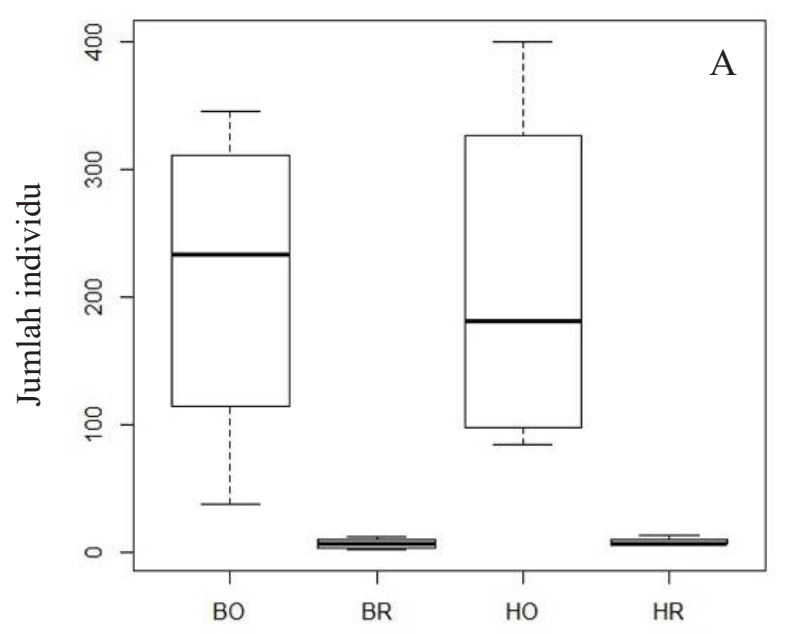

Tipe penggunaan lahan

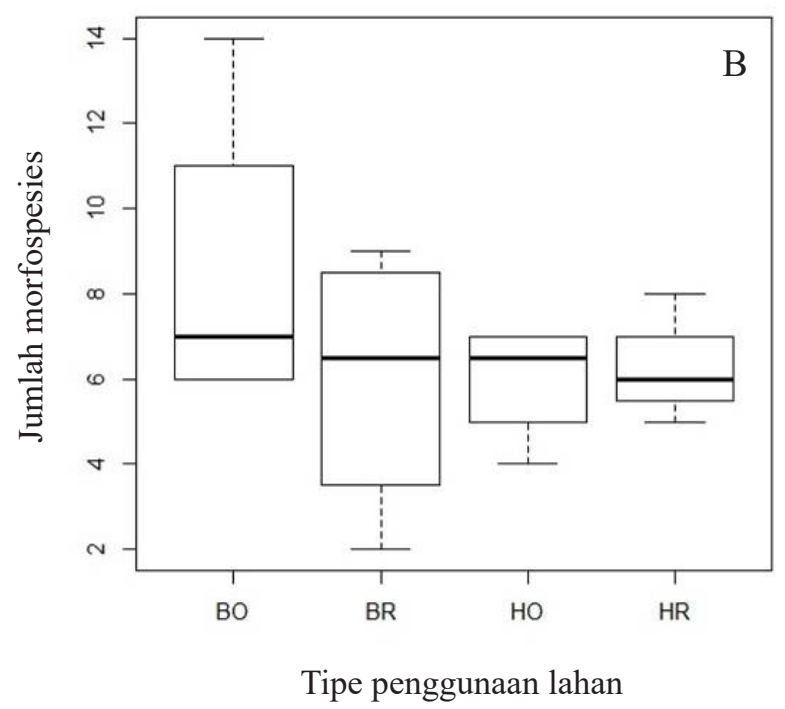

Gambar 5. Boxplot (A) kelimpahan dan (B) kekayaan spesies kumbang moncong pada dua tipe penggunaan lahan di Jambi. Kode awal B: Lanskap Taman Nasional Bukit Duabelas, dan H: Lanskap Hutan Harapan, diikuti oleh O: kelapa sawit, dan R: karet.
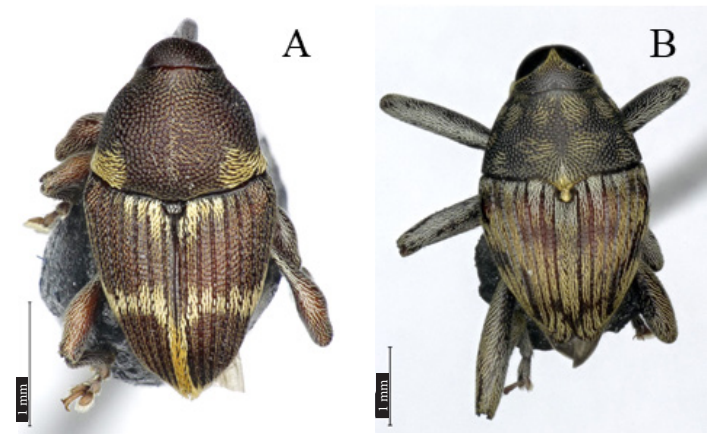

Gambar 6. Kumbang moncong yang hanya ditemukan di perkebunan karet. A: Curculio sp.04 dan B: Brimoides sp.02.

tidak memengaruhi komposisi spesies kumbang moncong dengan nilai kemiripan komposisi spesies (ANOSIM) sebesar $46 \%(\mathrm{R}=0,13$; $\mathrm{P}=0,14)$, namun perbedaan tipe penggunaan lahan memengaruhi komposisi spesies dengan nilai kemiripan komposisi spesies sebesar 4\%

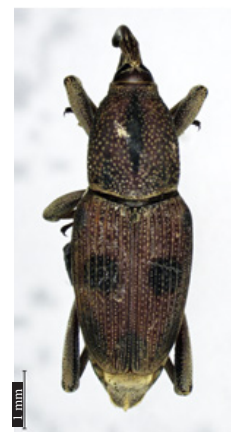

A

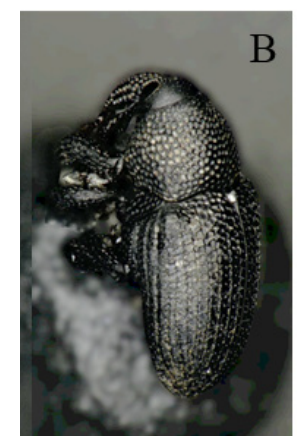

Gambar 7. Kumbang moncong yang hanya ditemukan di perkebunan kelapa sawit. A: Rhynchophorus sp.01 dan B: Baris sp.02.

$(\mathrm{R}=0,54 ; \mathrm{P}=0,001)($ Gambar 8). Nilai indeks keanekaragaman spesies Shannon-Wienner $\left(\mathrm{H}^{\prime}\right)$, kemerataan Evennes (E), keanekaragaman spesies Simpson (D) pada penggunaan lahan karet lebih tinggi dibandingkan dengan penggunaan lahan kelapa sawit, sedangkan pada kedua musim 
tergolong rendah dan tidak berbeda secara signifikan (Tabel 2). Tingginya nilai indeks H', E, dan D pada perkebunan karet menunjukkan bahwa perkebunan karet memiliki sebaran individu yang lebih merata serta kompleksitas komunitas yang lebih tinggi dibandingkan dengan perkebunan kelapa sawit.

\section{PEMBAHASAN}

Perbedaan tipe penggunaan lahan tidak berpengaruh terhadap kekayaan morfospesies kumbang moncong, namun kelimpahan individu kumbang moncong dipengaruhi oleh tipe penggunaan lahan. Perbedaan kelimpahan ini terjadi akibat adanya dominasi kumbang E. kamerunicus yang mendominasi pada tipe penggunaan lahan kelapa sawit. Hal sebaliknya terjadi pada hasil penelitian Najmi et al. (2018), perbedaan empat tipe penggunaan lahan di kawasan Hutan Harapan memengaruhi kekayaan spesies, namun tidak memengaruhi kelimpahan kumbang moncong.

Perbedaan tipe penggunaan lahan juga memengaruhi komposisi spesies kumbang

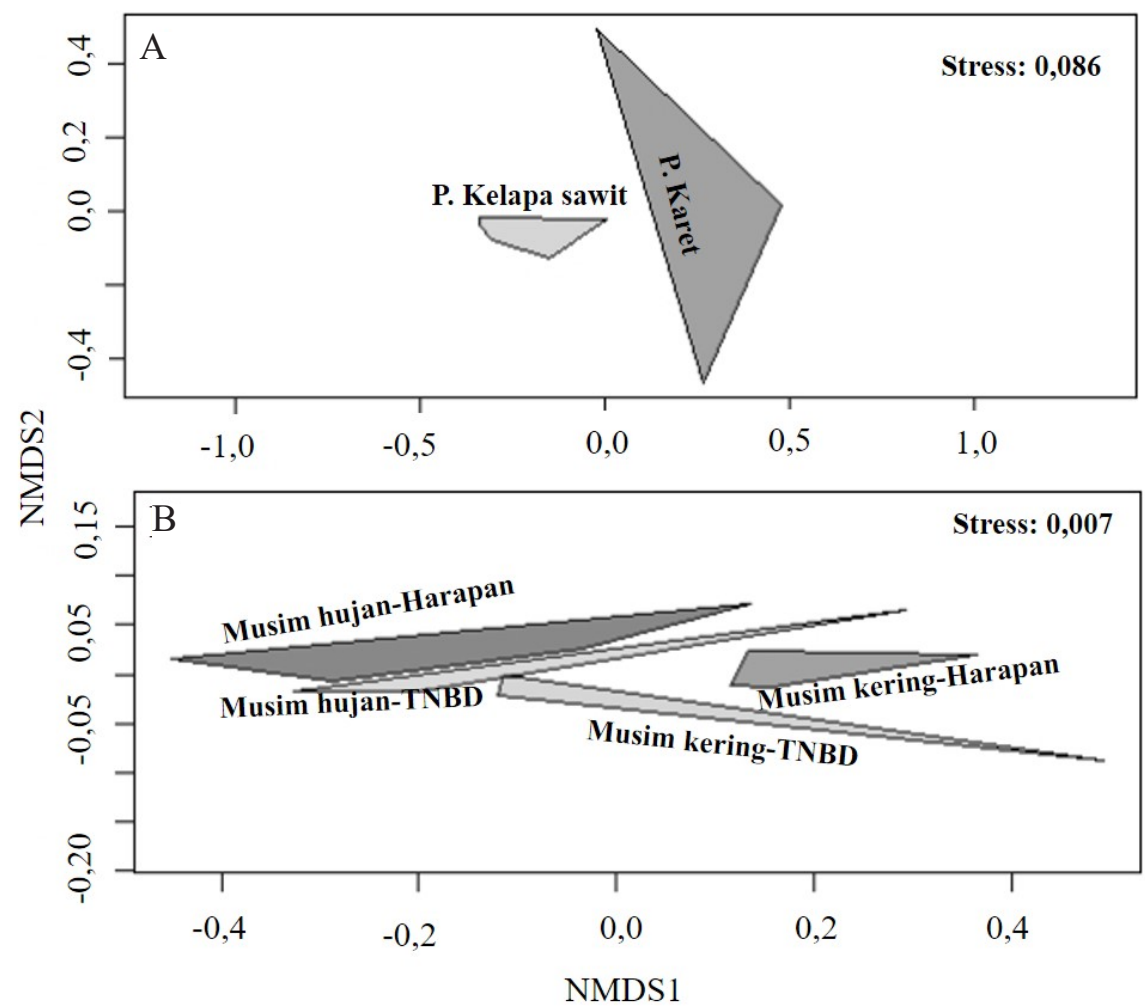

Gambar 8. NMDS komposisi kemiripan kumbang moncong pada A: tipe penggunaan lahan; B: musim dan lanskap.

Tabel 2. Nilai indeks keanekaragaman kumbang moncong pada musim dan tipe penggunaan lahan berbeda di Jambi

\begin{tabular}{lccccr}
\hline Indeks keanekaragaman & S & H' & E & D & N \\
\hline $\begin{array}{l}\text { Tipe penggunaan lahan } \\
\quad \text { Kelapa sawit }\end{array}$ & 29 & 0,375 & 0,111 & 0,111 & 1.700 \\
$\quad$ Karet & 30 & 3,162 & 0,929 & 0,947 & 61 \\
\hline Musim & & & & & \\
$\quad$ Musim kering & 32 & 0,890 & 0,257 & 0,275 & 442 \\
$\quad$ Musim hujan & 25 & 0,420 & 0,131 & 0,128 & 1.319 \\
\hline
\end{tabular}

S: kekayaan spesies; H': indeks keanekaragaman Shannon-Wienner; E: indeks kemerataan Evennes; D: indeks keanekaragaman Simpson; N: kelimpahan individu. 
moncong. Hal ini diduga disebabkan oleh rendahnya keanekaragaman dan tidak adanya kemiripan vegetasi di kedua tipe penggunaan lahan. Selain itu, kondisi mikroklimat dan tingginya intervensi manusia juga dapat memengaruhi komposisi kumbang yang ada di dalamnya. Perkebunan kelapa sawit juga biasanya memiliki habitat yang lebih terkelola dan terpelihara dengan baik dibandingkan dengan perkebunan karet (Chung et al. 2000; Klein et al. 2002).

Hasil analisis indeks keanekaragaman pada tipe penggunaan lahan kelapa sawit tergolong rendah, sedangkan pada tipe penggunaan lahan karet tergolong tinggi. Ludwig \& Reynolds (1988) menyatakan bahwa nilai indeks keanekaragaman spesies akan tinggi apabila jumlah spesies meningkat dan distribusi jumlah individu di masing-masing spesies sama banyak. Oleh karena itu, nilai indeks keanekaragaman pada tipe penggunaan lahan kelapa sawit tergolong rendah, sedangkan nilai indeks keanekaragaman di penggunaan lahan karet tergolong tinggi (Magurran 2004).

Salah satu penyebab tidak meratanya sebaran jumlah individu pada masing-masing morfospesies pada tipe penggunaan lahan perkebunan kelapa sawit adalah adanya spesies dominan, yaitu $E$. kamerunicus dengan jumlah 1.603 individu atau $94,30 \%$ dari total individu yang ditemukan di penggunaan lahan kelapa sawit. Hal ini karena E. kamerunicus merupakan penyerbuk utama tanaman kelapa sawit (Syed 1979). E. kamerunicus berasal dari negara Kamerun yang didatangkan ke Indonesia pada tahun 1983, yang kemudian dilepas pertama kali di kebun percobaan kelapa sawit Sungai Pancur, Sumatera Utara (Lubis 1992). Kumbang penyerbuk kelapa sawit ini kemudian menyebar dan berperan penting dalam proses penyerbukan kelapa sawit hingga saat ini di seluruh Indonesia.

Selain itu, E. kamerunicus juga ditemukan paling melimpah di musim hujan (77\%) dibandingkan dengan musim kering (23\%), hal ini disebabkan oleh curah hujan dan kelembaban yang berkorelasi positif dengan populasi E. kamerunicus (Dhileepan 1994). Selain menjadi spesies yang ditemukan paling melimpah pada penelitian ini, E. kamerunicus juga merupakan salah satu spesies yang ditemukan di kedua tipe penggunaan lahan. Meskipun jumlah individu yang ditemukan di perkebunan karet sangat sedikit, yaitu sebanyak 4 individu. Kehadiran kumbang E. kamerunicus pada penggunaan lahan karet diduga sebagai serangga yang hanya mengunjungi tanaman karet, yang dipengaruhi oleh jarak antara perkebunan karet dan habitat alaminya (perkebunan kelapa sawit) yang cukup dekat (Ricketts et al. 2008).

Kumbang Rhynchophorus sp.01 merupakan salah satu kumbang yang hanya ditemukan di perkebunan kelapa sawit. Genus Rhynchophorus merupakan bagian dari Subfamili Dryophthorinae (Anderson 2002), kumbang Rhynchophorus atau yang dikenal sebagai kumbang sagu adalah salah satu hama yang menyerang tanaman kelapa dan tanaman palem-paleman yang bisa menyebabkan kerusakan parah dan kematian pada tanaman (Abraham et al. 1998). Seluruh stadia kumbang Rhynchophorus hidup di dalam tanaman sehingga kumbang ini sulit untuk dikendalikan jika tidak dikendalikan sejak awal perkembangan (Abraham et al. 1998). Oleh karena itu, kumbang Rhynchophorus cukup berbahaya bagi tanaman kelapa sawit apabila populasinya cukup tinggi karena berpotensi menjadi hama pada tanaman kelapa sawit. Idris et al. (2014) melaporkan, terdapat spesies dari kumbang Rhynchophorus memiliki populasi yang cukup tinggi di perkebunan kelapa sawit di Malaysia dan berpotensi merusak tanaman kelapa sawit. Kumbang Rhynchophorus memiliki ciri khusus, yaitu berukuran cukup besar dengan garis hitam di kiri dan kanan kepala serta corak bulat hitam di bagian punggungnya (Anderson 2002).

Kumbang Curculio sp.04 merupakan salah satu kumbang yang hanya ditemukan di perkebunan karet, dan merupakan bagian dari Subfamili Curculioninae. Ciri khas khusus Genus Curculio, yaitu memiliki moncong yang ramping dan panjang yang terkadang lebih panjang dari tubuhnya (Anderson 2002). Ciri khas Curculio sp.04 ini adalah tubuh yang berwarna kecoklatan dan memiliki corak kuning pada bagian dorsal dan ventral. Whitehead et al. (2018) melaporkan beberapa spesies dari Genus Curculio menyerang biji-bijian dan kacang-kacangan berkulit keras. Salah satu spesies dari Genus Curculio juga 
ditemukan pada penelitian Najmi et al. (2018), yaitu sebagai salah satu spesies paling dominan yang ditemukan di tipe penggunaan lahan hutan.

\section{KESIMPULAN}

Perbedaan tipe penggunaan lahan tidak memengaruhi kekayaan spesies, tetapi memengaruhi kelimpahan individu dan komposisi spesies kumbang moncong. Jumlah individu pada tipe penggunaan lahan kelapa sawit lebih tinggi dibandingkan dengan tipe penggunaan lahan karet, namun kekayaan spesies tidak jauh berbeda. Terdapat 46\% kemiripan spesies antar musim dan $4 \%$ kemiripan spesies antar tipe penggunaan lahan. Hasil analisis indeks keanekaragaman pada tipe penggunaan lahan kelapa sawit lebih rendah dibandingkan dengan tipe penggunaan lahan karet. Spesies dominan yang ditemukan di kedua tipe penggunaan lahan adalah E. kamerunicus, sementara spesies yang spesifik ditemukan pada tipe penggunaan lahan kelapa sawit sebanyak 14 morfospesies (seperti Brimoides sp.02, Platypus sp.03, Ambrosiodmus sp.01, dan Hypothenemus sp.04) dan yang spesifik ditemukan pada tipe penggunaan lahan karet sebanyak 19 morfospesies (seperti Baris sp.02, Curculio sp.04, Treptoplatypus sp.01, dan Alniphagus sp.01).

\section{UCAPAN TERIMA KASIH}

Penulis mengucapkan terima kasih kepada proyek penelitian kolaborasi Indonesia-Jerman melalui CRC990-EFForTS (Ecological and Socioeconomic Functions of Tropical Lowland Rainforest Transformation Systems, http://www. uni-goettingen.de/crc990) terkhusus kepada Prof. Stefan Scheu dan Dr. Jochen Drescher serta seluruh pihak yang tidak dapat disebutkan satu persatu yang telah membantu berjalannya penelitian grup $\mathrm{Z} 02$.

\section{DAFTAR PUSTAKA}

Abraham VA, Al Shuaibi MA, Faleiro JR, Abozuhairah RA, Vidyasagar PSPV. 1998. An integrated management approach for red palm weevil Rhynchophorus ferrugineus Oliv. a key pest of date palm in the Middle East. Journal of Agricultural and Marine Sciences 3:77-83. doi: https://doi.org/10.24200/jams.vol3iss1pp77-83.

Amrulloh R. 2020. Keanekaragaman dan Kelimpahan Kumbang Daun (Coleoptera: Chrysomelidae) pada Empat Tipe Penggunaan Lahan di Lanskap Taman Nasional Bukit Duabelas dan Hutan Harapan, Jambi. Skripsi. Bogor: Institut Pertanian Bogor.

Anderson RS. 2002. Curculionidae Latreille 1802. Di dalam: Arnett RH, Thomas MC, Skelley PE, Frank JH (Eds.), American Beetles, Volume II: Polyphaga: Scarabaeoidea through Curculionoidea. hlm. 722-815. Florida: CRC Press.

Arnett RH, Thomas MC. 2001. American Beetles Volume I: Archostemata, Myxophaga, Adephaga, Polyphaga: Staphyliniformia. New York: CRC Press. doi: https://doi. org/10.1201/9781482274325.

Arnett RH, Thomas MC, Skelley PE, Frank JH. 2002. American Beetles, Volume II: Polyphaga: Scarabaeoidea through Curculionoidea. Florida: CRC Press. doi: https://doi. org/10.1201/9781420041231.

Borror DJ, Triplehorn CA, Johnson NF. 1996. Pengenalan Pelajaran Serangga. Partosoedjono $\mathrm{S}$, Brotowidjoyo MD, penerjemah. Yogyakarta: Gadjah Mada University Press. Terjemahan dari: Study of Insect. Ed ke-6.

Chung AYC, Eggleton P, Speight MR, Hammond PM, Chey VK. 2000. The diversity of beetle assemblages in different habitat types in Sabah, Malaysia. Bulletin of Entomological Research 90:475-496. doi: https://doi.org/10.1017/ S0007485300000602.

Dhileepan K. 1994. Variation in populations of the introduced pollinating weevil (Elaeidobius kamerunicus) (Coleoptera: Curculionidae) and its impact on fruitset of oil palm (Elaeis guineensis) in India. Bulletin Entomological Research 84:477-485. doi: https://doi. org/10.1017/S0007485300032703.

[Ditjenbun] Direktorat Jenderal Perkebunan. 2019a. Statitstik Perkebunan Indonesia 2017-2019: Kelapa Sawit. Jakarta: Direktorat Jenderal Perkebunan.

[Ditjenbun] Direktorat Jenderal Perkebunan. 2019b. Statitstik Perkebunan Indonesia 20172019: Karet. Jakarta: Direktorat Jenderal Perkebunan. 
Drescher J, Rembold K, Allen K, Beckschafer P, Buchori D, Clough Y, Faust H, Fauzi AM, Gunawan D, Hertel D, Irawan B, Jaya INS, Klarner B, Kleinn C, Knohl A, Kotowska MM, Krashevska V, Krishna V, Leuschner C, Lorenz W, Meijide A, Melati D, Nomura M, Pérez-Cruzado C, Qaim M, Siregar IZ, Steinebach S, Tjoa A, Tscharntke T, Wick B, Wiegand K, Kreft H, Scheu S. 2016. Ecological and socio-economic functions across tropical land use systems after rainforest conversion. Philosophical Transactions B 371:20150275. doi: https://doi.org/10.1098/rstb.2015.0275.

Faleiro JR, Ashok Kumar J, Rangnekar PA. 2002. Spatial distribution of red palm weevil Rhynchophorus ferrugineus Oliv. (Coleoptera: Curculionidae) in coconut plantations. Crop Protection 21:171-176. doi: https://doi. org/10.1016/S0261-2194(01)00083-7.

Hangay G, Zborowski P. 2010. A Guide to the Beetles of Australia. Victoria: CSIRO Publishing. doi: https://doi.org/10.1071/9780643100121.

Hiola MS. 2019. Keanekaragaman Kumbang Jelajah Arboreal (Coleoptea: Staphylinidae) di Lanskap Hutan Harapan dan Taman Nasional Bukit Duabelas, Jambi. Tesis. Bogor: Institut Pertanian Bogor.

Idris AB, Mokhtaruddin H, Zazali C, Nurul Wahida O, Yaakop S, Hazmi IR. 2014. The potential of red palm weevil infesting and destroying oil palm industry in Malaysia. Planter 90:329-335.

Kasmiatun, Nazarreta R, Hidayat P, Buchori D. 2020a. Diversity and species composition of click beetles (Coleoptera: Elateridae) at different land-use types in Harapan Rainforest landscape, Jambi, Indonesia. IOP Conference Series: Earth and Environmental Science 468:012015. doi: https://doi.org/10.1088/17551315/468/1/012015.

Kasmiatun, Nazarreta R, Buchori D. 2020 b. Keanekaragaman dan komposisi kumbang elaterid (Coleoptera: Elateridae) di kawasan hutan hujan tropis Taman Nasional Bukit Duabelas dan Hutan Harapan, Jambi. Jurnal Entomologi Indonesia 17:33-44. doi: https://doi. org/10.5994/jei.17.1.33.

Kippenberg. 2018. Family Curculionidae, Keys to British subfamilies of Family Curculionidae (Coleoptera). Hackston M, translator and adapter. Translated from: Die Käfer Mitteleuropas, volume 10. Tersedia pada: https://sites.google. com/site/mikesinsectkeys/Home/keys-tocoleoptera/keys-to-british-species-of-familycurculionidae. [diakses 11 Januari 2019].
Klein AM, Stefan-Dewenter I, Buchori D, Tscharntke T. 2002. Effects of land-use intensity in tropical agroforestry systems on coffee flower-visiting and trap-nesting bees and wasps. Conservation Biology 16:1003-1014. doi: https://doi. org/10.1046/j.1523-1739.2002.00499.x.

Lawrence JF, Britton EB. 1991. Coleoptera. Di dalam: Naumann ID (Ed.), The Insects of Australia, Second Edition, Volume II. hlm. 543683. Victoria: Melbourne University Press.

Lubis AU. 1992. Kelapa Sawit (Elaeis guineensis Jacq) di Indonesia. Bandar Kuala, Sumatera Utara: Pusat Penelitian Kelapa Sawit Marihat.

Ludwig JA, Reynolds JF. 1988. Statistical Ecology. New York: John Wiley \& Sons.

Magurran AE. 2004. Measuring Biological Diversity. Oxford: Blackwell Science Publishing.

Mumme S, Jochum M, Brose U, Haneda NF, Barnes AD. 2015. Functional diversity and stability of litter-invertebrate communities following landuse change in Sumatra, Indonesia. Biological Conservation 191:750-758. doi: https://doi. org/10.1016/j.biocon.2015.08.033.

Najmi L, Buchori D, Triwidodo H, Noerdjito WA, Rizali A. 2018. Keanekaragaman kumbang curculionid pada berbagai tipe penggunaan lahan di kawasan Hutan Harapan, Jambi. Jurnal Entomologi Indonesia 15:65-73. doi: https://doi. org/10.5994/jei.15.2.59.

Oberprieler RG, Marvaldi AE, Anderson RS. 2007. Weevils, weevils, weevils everywhere. Zootaxa 1668:491-520. doi: https://doi.org/10.11646/ zootaxa.1668.1.24.

O'Brien CW, Woodruff RE. 1986. First record in the United States and South America of the African oil palm weevils, Elaeidobius subvittatus (Faust) and E. kamerunicus (Faust) (Coleoptera: Curculionidae). Entomology Circular 284. Florida Department of Agriculture and Consumer Services, Division of Plant Industry.

Ricketts TH, Regetz J, Steffan-Dewenter I. Cunningham SA, Kremen C, Bogdanski A, Gemmil-Harren B, Greenleaf SH, Klein AM, Mayfield MM, Morandin LA, Ochieng' A, Potts SG, Viana BF. 2008. Landscape effects on crop pollination service: are the general patterns?. Ecology Letter 11:499-515. doi: https://doi. org/10.1111/j.1461-0248.2008.01157.x.

Syed RA. 1979. Studies on oil palm pollination by insects. Bulletin of Entomological Research 69:213-224. doi: https://doi.org/10.1017/ S0007485300017673.

Whitehead DR, Chamorro ML, Anderson RS. 2018. An illustrated key to the species of Curculio 
Linnaeus (Coleoptera: Curculionidae) of North America East of the Mississippi river. Proceedings of the Entomological Society of Washington 120:616-641. doi: https://doi. org/10.4289/0013-8797.120.3.616. 